DOI 10.15290/cnisk.2020.01.08.09

MARIA BAUCHROWICZ-TOCKA

https://orcid.org/0000-0003-1691-2568

Uniwersytet w Białymstoku

\title{
Ewolucja celów Ligi Kobiet w latach 1945-1989 w świetle jej statutów ${ }^{1}$
}

\section{Streszczenie}

W 1945 r. została powołana Społeczno-Obywatelska Liga Kobiet (SOLK). Była masową organizacją kobieca, która w latach 1945-1989, wyznaczających zmiany ustroju w kraju, dwukrotnie zmieniała nazwę i ośmiokrotnie statut. W 1949 r. kontynuatorką SOLK była Liga Kobiet, a w 1982 r. Liga Kobiet Polskich.

Artykuł prezentuje ewolucję celów i zadań Ligi w latach 1945-1989. Do jej przedstawienia posłużyły kolejne statuty organizacji. Ich analiza prowadzi do wniosku, że Liga Kobiet służyła popieraniu ówczesnego ustroju i kształtowaniu politycznej świadomości kobiet, a jednocześnie zabiegała o ich szeroko pojęte prawa (podnoszenie kwalifikacji, warunki pracy, aktywność zawodową i społeczna). Ewolucja celów organizacji ukazana została na tle przełomowych wydarzeń w kraju.

Słowa kluczowe: Liga Kobiet, organizacja kobieca, polityka w PRL, system komunistyczny

1 Artykuł przygotowany w ramach realizacji projektu badawczego Narodowego Centrum Nauki pt. Liga Kobiet w terenie. Działalność organizacji i realia jej funkcjonowania na szczeblu regionalnym i lokalnym w rzeczywistości Polski Ludowej (1945-1989) - nr 2017/25/B/HS3/02015. 


\title{
EVOLUTION OF THE AIMS OF THE LEAGUE OF WOMEN IN THE YEARS 1945-1989 IN THE LIGHT OF ITS STATUTES
}

\begin{abstract}
In 1945, the Socio-Civic League of Women (SCLW) had been established. It was a women's mass organization which in the years 1945-1989 changed its name twice and the statute eight times. The mentioned period of time was significant for the changes of the political system of the country. In 1949, the League of Women continued the works of SCLW and in 1982 the League of Polish Women took this role.

The article presents the changes in aims and tasks of the League in the years 1945-1989. In order to describe them, the organization's statutes were used. Their analysis leads to the conclusion that the Women's League was a tool to support the political system in the country at the time and to raise political awareness among women; at the same time it advocated for their broadly understood rights (improving qualifications, working conditions, professional and social activity). The evolution of the organization's aims is presented against the backdrop of the key events in the country.
\end{abstract}

Keywords: the League of Women, women's organization, politics in the Polish People's Republic, the Communist system

\section{Wstęp}

Liga Kobiet, masowa organizacja kobieca o politycznym charakterze, która działała w Polsce Ludowej, w latach 1945-1989 dwukrotnie zmieniała nazwę i ośmiokrotnie statut ${ }^{2}$. Została powołana w $1945 \mathrm{r}$. pod nazwa Społeczno-Obywatelska Liga Kobiet (SOLK)³. We wrześniu 1949 r. zmieniła nazwę i kontynuatorka SOLK była Liga Kobiet (LK) ${ }^{4}$.

\footnotetext{
2 W artykule zamiennie używam nazw organizacji, ich skrótów i określenia Liga.

3 Według ustaleń Adama Miodowskiego SOLK powstała w lipcu 1945 r. Adam Miodowski, „Rozwój dolnośląskich i zachodniopomorskich struktur Społeczno-Obywatelskiej Ligi Kobiet w latach 1947-1949 w świetle publikacji "Naszej Pracy»", w: Małgorzata Dajnowicz, Adam Miodowski (red.), Polityka i politycy w prasie XX i XXI wieku. Polityka w prasie kobiecej, (Białystok: Wydawnictwo Uniwersytetu w Białymstoku, 2019), 168. Do Rejestru stowarzyszeń i związków miasta stołecznego Warszawy SOLK została wpisana 6.11.1945 r. pod numerem 35. „Statut SOLK”, Archiwum Akt Nowych (dalej: AAN), Zespół Ministerstwa Polityki i Opieki Społecznej (1945-1946), nr 402, sygn. 300, k. 104-105.

4 Rozporządzenie Rady Ministrów z dnia 9.09.1949 r. w sprawie uznania stowarzyszenia „Liga Kobiet” za stowarzyszenie wyższej użyteczności, Dz.U. 1949, nr 51, poz. 385 [online] [dostęp: 10.11.2019]. Dostępne w World Wide Web: http://isap.sejm.gov.pl.
} 
Kolejna zmiana nazwy organizacji, na Ligę Kobiet Polskich (LKP), nastapiła w grudniu $1982 \mathrm{r}^{5}$

Cele nakreślone w kolejnych edycjach statutu organizacji odzwierciedlały jej ewolucję, która była spójna z politycznymi i społecznymi przemianami w kraju, wytyczonymi przez wiodaca partię: najpierw Polską Partię Robotniczą (PPR), a następnie Polską Zjednoczoną Partię Robotnicza ${ }^{6}$. LK była podporzadkowana partyjnej władzy, realizowała, wspierała i upowszechniała jej ideologię. Problematyka Ligi Kobiet i aktywność jej członkiń budzi zainteresowanie badaczy. W ostatnim okresie ukazało się kilka interesujacych rozpraw ${ }^{7}$. Intencja artykułu jest zaprezentowanie ewolucji celów i założeń programowych Ligi Kobiet w latach 1945-1989. Graniczne daty wyznaczaja zmiany ustrojowo-polityczne w kraju. W tym okresie zamyka się działalność organizacji kobiecej od jej powołania po zakończeniu II wojny światowej do końca sprawowania władzy państwowej przez PZPR ${ }^{8}$. Do prezentacji zagadnienia wykorzysta-

5 Rozporządzenie Rady Ministrów z dnia 2.12.1982 r. w sprawie zmiany nazwy stowarzyszenia wyższej użyteczności „Liga Kobiet” na „Liga Kobiet Polskich” oraz nadania statutu temu stowarzyszeniu, Dz.U. 1982, nr 38, poz. 254 [online], [dostęp: 10.11.2019]. Dostępne w World Wide Web: http:/ isap.sejm.gov.pl.

6 Na Kongresie Zjednoczeniowym 15.12.1948 r. doszło do połączenia PPR z PPS i utworzenia Polskiej Zjednoczonej Partii Robotniczej (PZPR).

7 Małgorzata Dajnowicz, „Działalność Społeczno-Obywatelskiej Ligi Kobiet w świetle "Naszej Pracy" (1947-1949)", w: Małgorzata Dajnowicz, Adam Miodowski (red.), Polityka i politycy w prasie XIX i XX wieku, (Białystok: Wydawnictwo Humanica, 2016), 295-307; eadem, "Główne kierunki działalności Ligi Kobiet w Polsce Ludowej do 1975 roku (ze szczególnym uwzględnieniem województwa białostockiego)", Zeszyty Naukowe Uniwersytetu Jagiellońskiego. Prace Historyczne, t. 145, z. 3, 2018, 579-601; eadem, "Zwierciadło" - platforma polityczna Ligi Kobiet w okresie PRL (1957-1961, 1982-1989)", Rocznik Historii Prasy Polskiej, t. 20, z. 3(47), 2017, 67-90; eadem, „Posłanki Ligi Kobiet Polskich i wybory parlamentarne 1989 roku (prezentacja w świetle "Zwierciadła»)", w: Małgorzata Dajnowicz, Adam Miodowski (red.), Polityka i politycy w prasie XX i XXI wieku. Polityka $w$ prasie kobiecej, (Białystok: Wydawnictwo Uniwersytetu w Białymstoku, 2019), 205-215; Adam Miodowski, „Rozwój dolnośląskich”, 167-183; Agnieszka Drozdowska, „O działalności Ligi Kobiet w okręgu białostockim (w świetle "Naszej Pracy»)", w: Małgorzata Dajnowicz, Adam Miodowski (red.), Polityka i politycy w prasie XX i XXI wieku. Polityka w prasie kobiecej, (Białystok: Wydawnictwo Uniwersytetu w Białymstoku, 2019), 185-204; eadem, „Działalność Ligi Kobiet w północno-wschodniej części Polski Ludowej w latach 1975-1989 w świetle "Naszej Pracy»", Niepodległość i Pamięć, nr 2, 2019, 184 210; Urszula Ćwik, „Podstawowe założenia Społeczno-Obywatelskiej Ligi Kobiet w świetle "Mody i Życia Praktycznego" (1946-1951)", w: Małgorzata Dajnowicz, Adam Miodowski (red.), Polityka i politycy $w$ prasie XX $i$ XXI wieku. Prasa organizacji politycznych, (Białystok: Wydawnictwo Humanica, 2017), 49-58.

8 Uchwała o rozwiazaniu PZPR podjęta została na XI Zjeździe partii, (obradował 2829.01.1990 r.). PZPR formalnie zakończyła działalność 30.01.1990 r. 
ne zostały kolejne statuty: SOLK, LK i LKP. Główną metodą badawczą była ich analiza porównawcza.

\section{Kontynuacja w nazwie}

Społeczno-Obywatelska Liga Kobiet z 1945 r. nawiazywała nazwa do patriotyczno-niepodległościowej Ligi Kobiet z 1913 r. ${ }^{9}$ Tylko nazwa, inne były bowiem cele powołanej w czasie zaborów organizacji kobiecej i charakter jej działalności. Głównym zadaniem działających w konspiracji kobiet, skupionych najpierw w Lidze Kobiet Pogotowia Wojennego, a następnie w Lidze Kobiet Polskich, było wspieranie ruchu wojskowego, budzenie dążeń niepodległościowych, a po wybuchu I wojny światowej organizowanie pomocy żołnierzom polskim (członkinie organizowały zbiórki żywności i odzieży dla żołnierzy, wysyłały paczki na front, opiekowały się rannymi, otaczały opieką rodziny walczących na wojnie) oraz prowadzenie działalności propagandowej na rzecz walki o niepodległość ${ }^{10}$. W statucie Ligi Kobiet Polskich $z$ września 1917 r., podpisanym przez Zofię Moraczewską (drugi podpis nieczytelny), i w statucie LKP złożonym 9 kwietnia 1919 r. do rejestracji stowarzyszenia ${ }^{11}$ zapisano, że głównym celem Ligi jest „współdziałanie w dźwiganiu kraju z ruiny, spowodowanej wojną"12. W paragrafie poświęconym celom wyszczególniono: podniesienie oświaty, kultury i dobrobytu wśród najszerszych warstw społeczeństwa polskiego w mieście i na wsi; opiekę nad „dziatwą sieroca i bezdomną"; opiekę nad inwalidami, żołnierzami Wojska Polskiego i ich rodzinami, niesienie pomocy materialnej ludziom dotkniętym wojną oraz walkę $z$ wyzyskiem i lichwą, wywołanymi stosunkami wojennymi ${ }^{13}$.

\footnotetext{
9 W 1913 r. powstała Liga Kobiet Polskich Pogotowia Wojennego, a dwa lata później Liga Kobiet Galicji i Śląska. Obie Ligi połączyły się, tworząc Ligę Kobiet Polskich. Na czele zarządu stanęła Zofia Moraczewska. Joanna Dufrat, „Powstanie Ligi Kobiet i działalność w okresie I wojny światowej” [online] [dostęp: 1.07.2020]. Dostępny w World Wide Web: http:/ /ligakobietpolskich.pl/wp-content/uploads/2013/12/Powstanie-Ligi-Kobiet-i-dzia\%C5\%82alno\%C5\%9B\%C4\%87-w-okresie-I-wojny-\%C5\%9Bwiatowej_dr_Dufrat.pdf.

10 Joanna Dufrat, „Powstanie Ligi Kobiet”, 3.

11 Stowarzyszenie Liga Kobiet Polskich zostało wpisane do rejestru stowarzyszeń i związków pod nr 64 w dniu 1.07.1919 r., Statut Towarzystwa Ligi Kobiet Polskich, AAN, zespół Liga Kobiet Polskich, 57/II, sygn. 150, k. 8.

12 Statut Towarzystwa Ligi Kobiet Polskich, AAN, zespół Liga Kobiet Polskich 57/II, sygn. 37, k. 29-37 i sygn. 150, k. 1-8.

13 Ibidem. W statucie z 1917 r. wśród wypisanych celów było „podniesienie przemysłu i wytwórczości krajowej" (nie ma tego zapisu w statucie z 1919 r.), ale nie sformułowano
} 
W statucie Ligi Kobiet z 2 marca 1928 r. zapisany został tylko jeden cel: „dążenie do odrodzenia życia publicznego w Polsce, przez podniesienie oświaty, kultury i poziomu moralnego oraz przez budzenie cnót obywatelskich wśród najszerszych warstw społeczeństwa" ${ }^{14}$.

Społeczno-Obywatelska Liga Kobiet $z$ lat 1945-1949 funkcjonowała w innej rzeczywistości politycznej, w komunistycznym ustroju. Wspólne dla Ligi $z$ okresu po I wojnie światowej i SOLK były głównie dażenia do odbudowy, do „dźwigania kraju z ruiny”, jak to określono w statucie $z 1919 \mathrm{r}$.

\section{Społeczno-Obywatelska Liga Kobiet (1945-1949)}

W pierwszym okresie SOLK działała według wytycznych programu, zawartych w „Deklaracji ideowej Społeczno-Obywatelskiej Ligi Kobiet” (dokument nie posiada daty) ${ }^{15}$. „Deklarację” rozpoczynała preambuła:

Przeszło pięć lat ciążył nad nami straszliwy koszmar niewoli hitlerowskiej ... Dzięki bohaterskiej walce naszego ludu, dzięki bohaterstwu polskiego partyzanta i polskiego żołnierza, który przelewał krew swoja na wszystkich frontach świata, dzięki armiom sojuszniczym - zmartwychwstała Polska. Zaczęła się wielka praca nad odbudową Ojczyzny naszej. I my, kobiety polskie, w pracy tej bierzemy wielki udział ${ }^{16}$.

Jak widać, już we wstępie wyeksponowana została rola kobiet w budowaniu nowej rzeczywistości.

W „Deklaracji” nakreślono zadania dla kobiet polskich: walka z faszyzmem, utrwalanie pokoju, utrwalanie demokracji, udział w życiu społecznym i państwowym, udział w odbudowie kraju, w budowie Polski demokratycznej. Prócz tych ogólnych haseł były także szczegółowe wytyczne. "Chcemy, by się z nami liczono, by nie stanowiono nic o nas bez nas”. W „Deklaracji” napisano, aby zostało wcielone w życie

\footnotetext{
dążenia do „walki z wyzyskiem i lichwą, wywołanymi stosunkami wojennymi” (zapis ten jest w statucie $z 1919$ r.).

14 Statut Towarzystwa „Liga Kobiet” zatwierdzony przez Komisariat Rządu na m.st. Warszawę w dn. 2 marca 1928 r., AAN, zespół Liga Kobiet Polskich 57/II, sygn. 150, k. 33.

15 Deklaracja ideowa Społeczno-Obywatelskiej Ligi Kobiet, AAN, zespół Społeczno-Obywatelska Liga Kobiet, Zarząd Główny w Warszawie, nr 888, sygn. 1, k. 8-10.

16 Ibidem, k. 8.
} 
równouprawnienie. Kobiety domagały się równej z mężczyznami płacy za tę samą pracę, przy równych kwalifikacjach równych $z$ mężczyznami stanowisk, dostępu do szkół zawodowych i wszystkich zawodów. Zakładano, że działaczki kół Ligi Kobiet, których sieć miała pokryć kraj, będą dążyły do polepszenia warunków materialnych, zdrowotnych i kulturalnych rodzin. Miało temu służyć zakładanie żłobków, przedszkoli, świetlic, stołówek, pralni, spółdzielni, organizowanie kursów, rozrywek, wczasów.

W „Deklaracji” osiem razy użyto zwrotu „my kobiety”, co z pewnościa służyło podkreśleniu roli, jaka organizacja zamierzała spełniać wśród kobiet, a także wskazaniu, że w Lidze jest miejsce dla wszystkich kobiet (pracujacych i niepracujacych, mieszkajacych na wsi i w mieście, bardziej i mniej wykształconych). Było w niej także stwierdzenie o przyjaźni ze wszystkimi narodami demokratycznymi, a szczególnie ze Związkiem Radzieckim jako „gwarancją polskiej niepodległości i szybkiej odbudowy kraju”.

Zapisy w „Deklaracji ideowej SOLK” nawiązywały do ówczesnej rzeczywistości. Organizacja nie działała w izolacji, od początku trwała w politycznej zależności od komunistycznego kierownictwa kraju. Zmiany zachodzące w Lidze, czego wyrazem były zapisane w kolejnych statutach cele, zwiazane były $z$ przeobrażeniami życia politycznego i społecznego kraju.

Pierwszy statut SOLK został uchwalony 9 września 1945 r. ${ }^{17}$ Miał dziewiętnaście paragrafów przedstawionych na dwóch stronach.

17 Dokument nie ma nazwy „Statut” ani daty. Sa w nim przedstawione cele i struktura organizacji (Zarząd Główny, zadania komisji rewizyjnej, zasady powoływania kół). Znajduje się w AAN w zespole Ministerstwa Pracy i Opieki Społecznej (lata 1945-1946). Jest załącznikiem do pisma przewodniego (L.dz. II/766/46) skierowanego do Ministerstwa Pracy i Opieki Społecznej z data 1.10.1946 r., podpisanego przez kierownika organizacyjnego ZG SOLK D. Nagórską i dyrektor Biura ZG M. Rosochacką. Nagórska i Rosochacka pisza, że przesyłają w załączeniu listę członkiń Zarządu Głównego SOLK oraz statut. Należy uznać, że chociaż dokument nie ma nagłówkowej nazwy, jest statutem (tak go nazywały członkinie i pracownice ZG SOLK). Na drugiej stronie statutu jest Odpis decyzji Prezydenta m.st. Warszawy z dnia 6.11.1946 r. (tu wystapiła omyłka pisarska, powinno być 1945 r., obok błędnego roku jest L.dz. 011-3499/45, wskazująca na rok 1945) o wpisaniu do Rejestru stowarzyszeń i związków pod nr 35 Stowarzyszenia pod nazwą Społeczno-Obywatelska Liga Kobiet. Zgodność odpisu potwierdziła sekretarz ZG SOLK Izolda Kowalska. AAN, zespół Ministerstwa Pracy i Opieki Społecznej (dalej: MPiOS) (1945-1946), nr 402, sygn. 300, k. 102-105 (pismo przewodnie k. 102, lista członkiń ZG SOLK k. 103, statut k. 104-105). Weronika Jackowska, „Z 35-letniej historii Ligi Kobiet”, Nasza Praca (dalej: NP), nr 2, 1980, 14. 
Cele organizacji w 1945 r. zostały sformułowane w ukierunkowany, choć jeszcze dość ogólny sposób. Określono, że „Liga zmierzać będzie do skupienia w swych szeregach najszerszych mas kobiecych, prowadząc pracę ideowo-wychowawczą oraz broniąc praw i interesów szerokiego ogółu kobiet"18.

Wśród celów wymienionych w statucie było dążenie do: rozbudowy ustaw ochronnych, pogłębiania opieki społecznej, głównie opieki nad matka i dzieckiem, podnoszenia kultury życia rodzinnego, rozwoju ruchu spółdzielczego i budownictwa mieszkaniowego oraz popularyzacji zagadnień, zwiazanych z życiem kobiet wiejskich i miejskich. Realizacji tych celów miało służyć powoływanie kół Ligi, placówek szkoleniowych, ośrodków pracy społecznej i opiekuńczej, organizowanie pokazów i szkoleń oraz powołanie Naukowego Instytutu Gospodarstwa Domowego. Rola Instytutu miało być naukowe opracowanie podstaw organizacji gospodarstwa domowego, zdrowego odżywiania, zasad higieny.

Można ocenić, że nakreślone w statucie cele zmierzały do budzenia społecznej i zawodowej aktywności, służyły rozwojowi kobiet (w statucie napisano o „wyrobieniu kobiet”). Służyły też budzeniu politycznej świadomości. Zakładano, że organizacja będzie masowa. W październiku 1946 r. funkcjonowało 14 zarządów wojewódzkich LK, dwa zarządy w miastach wydzielonych (w Warszawie i Łodzi), w 14 województwach w $90 \%$ były zorganizowane zarządy powiatowe, które skupiały koła wiejskie i miejskie ${ }^{19}$. Liga liczyła wówczas ok. 190 tys. członkiń.

W roku 1946 nastapily ważne wydarzenia polityczne. 30 czerwca przeprowadzono referendum „3 3 tak”, które miało wskazywać na poparcie i zaufanie do rzadzacych, wprowadzono cenzurę, trwała kampania przedwyborcza do Sejmu Ustawodawczego (SU). W akcję wyborcza angażowała się Liga. Do prac propagandowo-agitacyjnych przeszkolone zostały 3083 kobiety $^{20}$.

18 Statut Społeczno-Obywatelskiej Ligi Kobiet, AAN, zespół MPiOS, nr 402, sygn. 300, k. 104-105.

19 Pismo kierownika organizacyjnego ZG SOLK D. Nagórskiej i dyrektor Biura ZG M. Rosochackiej do Ministerstwa Pracy i Opieki Społecznej z 1.10.1946 r., AAN, zespół MPiOS (1945-1946), nr 402, sygn. 300, k. 102.

20 Małgorzata Dajnowicz, „Działalność Społeczno-Obywatelskiej Ligi Kobiet w świetle "Naszej Pracy" (1947-1949)", w: Małgorzata Dajnowicz, Adam Miodowski (red.) Polityka i politycy w prasie XIX i XX wieku, (Białystok: Wydawnictwo Humanica, 2016), 299. 
Drugi, znacznie obszerniejszy (66 paragrafów), statut SOLK pochodzi z 1947 r. ${ }^{21}$ Organizacja wytyczyła pięć celów: „walka o stały i sprawiedliwy pokój świata, oparty na zasadach demokratycznych; obrona praw i interesów kobiety, obrona interesów rodziny ze szczególnym uwzględnieniem interesów dziecka; wychowanie kobiety, obywatelki świadomej swych praw i obowiązków w stosunku do ojczyzny i społeczeństwa; czynny udział w pracy państwa i w jego odbudowie"22.

W statucie oprócz zapisów o dą̇̇eniu do pokoju i o szeroko nakreślonych prawach kobiet były też zawarte obowiąki. W odbudowę kraju, co było koniecznościa, angażowały się kobiety, także członkinie Ligi, uczestniczace w Planie Odbudowy Gospodarczej (plan trzyletni 19471949). Dziś można przypuszczać, że pod określeniem „udziału w pracy państwa” chodziło o legitymizację rządu. W styczniu 1947 r. odbyły się wybory do Sejmu Ustawodawczego, a po nich wybory nowych władz: prezydentem został Bolesław Bierut (5 lutego), utworzono rząd $z$ Józefem Cyrankiewiczem na czele, a Władysław Gomułka został wicepremierem (8 lutego). Także w lutym (19.) uchwalono mała konstytucję. Aktywna działalność organizacji o silnej i systematycznie rozbudowującej się strukturze, uwiarygodniała partyjno-rządowe decyzje.

\section{Liga Kobiet (1949)}

9 września 1949 r. SOLK przyjęła nazwę Liga Kobiet i nowy statut, obowiazujący od 5 października 1949 r. ${ }^{23}$ Był to czas umacniania komunistycznej władzy i utrwalania ustroju, przebudowy struktury społeczno-gospodarczej kraju, kolektywizacji wsi, nacjonalizacji przemysłu, antykościelnej propagandy, odbudowy kraju i powszechnej indoktrynacji komunistycznej.

W tym okresie Liga Kobiet, podobnie jak inne wówczas powoływane organizacje, została włączona w ideologię i politykę sterowaną przez

\footnotetext{
21 Statut Społeczno-Obywatelskiej Ligi Kobiet, AAN, zespół MPiOS (1947-1948), nr 402, sygn. 323, k. 1-9.

22 Ibidem, k. 1-2.

${ }^{23}$ Rozporządzenie Rady Ministrów z dnia 9 września 1949 r. w sprawie uznania stowarzyszenia „Liga Kobiet” za stowarzyszenie wyższej użyteczności, Dz.U. 1949, nr 51, poz. 385; Obwieszczenie Prezesa Rady Ministrów z dnia 5 października 1949 r. w sprawie ogłoszenia statutu stowarzyszenia wyższej użyteczności „Liga Kobiet”, M.P. 1949, nr 73, poz. 923, obydwa dokumenty: [online] [dostęp: 10.11.2019]. Dostępne na World Wide Web: http:// prawo.sejm.gov.pl.
} 
PZPR i Zwiazek Radziecki. Odbiciem tej rzeczywistości były cele organizacji przedstawione w statucie w czterech punktach. Nakreślone trzy pierwsze zadania świadczyły o znacznym upolitycznieniu organizacji:

1. Wychowywanie kobiet w duchu patriotyzmu dla Polski Ludowej oraz w duchu solidarności międzynarodowej z obozem postępu, a w szczególności z kobietami całego świata, walczącymi o pokój, postęp i sprawiedliwość społeczna, krzewienie uczuć przyjaźni do Związku Radzieckiego. 2. Podnoszenie poziomu politycznego i kulturalnego szerokich rzesz kobiecych i wyjaśnianie im ich roli w budowie Polski Socjalistycznej. 3. Włączenie kobiet do twórczej pracy nad rozbudowa kraju i budową fundamentów socjalizmu ${ }^{24}$.

Kolejnym celem Ligi było dążenie do pełnego równouprawnienia kobiet przez ich awans społeczny, podnoszenie kwalifikacji zawodowych, rozbudowę opieki nad matką i dzieckiem oraz racjonalizację gospodarstwa domowego. Te zapisy można odebrać jako symptomy nowego ustroju, który dostrzegał ważna rolę kobiet w społeczeństwie i troszczył się o ich rozwój i awans. Ale jednocześnie trzeba pamiętać, że zawodowa aktywność kobiet była wówczas jeszcze koniecznościa. Po wojnie brakowało rak do pracy i kobiety musiały pracować, także w zawodach uważanych za męskie (w górnictwie, budownictwie, hutnictwie). Koła Ligi (organizacji dbającej o interesy kobiet) powstawały w zakładach, fabrykach, kopalniach, w których znaczna część załogi tworzyły kobiety. Liga starała się pomóc kobietom w pogodzeniu obowiąków rodzinnych $\mathrm{z}$ zawodowymi, dlatego w statucie pojawił się zapis zracjonalizowania gospodarstw domowych. „Zniknęły” ze statutu wcześniej obecne zapisy dotyczace rozwoju ruchu spółdzielczego i budownictwa mieszkaniowego. W tym czasie LK stała się organizacją masową. W końcu 1950 r. organizacja liczyła ok. 1714 tys. członkiń skupionych w 38653 kołach $^{25}$.

Należy także zwrócić uwagę na nowy zapis zawarty w rozdziale XII statutu. Określał on, że Liga Kobiet podlega nadzorowi państwowemu. Delegata do wykonywania stałego nadzoru nad Liga mianował Minister Administracji Publicznej. W przypadku, gdyby wymagał tego interes państwa, LK miała być podporządkowana Ministrowi Administracji Publicznej. Ten zapis świadczył także o zależności od partyjnego rządu.

${ }^{24}$ Obwieszczenie Prezesa Rady Ministrów z dnia 5 października 1949...

25 Małgorzata Dajnowicz, „Główne kierunki działalności Ligi Kobiet”, 586. 


\section{Liga Kobiet (1951)}

I kongres Ligi Kobiet odbył się 3 i 4 marca 1951 r. ${ }^{26}$ Na kongresie zostały wybrane nowe władze organizacji (funkcje przewodniczacej po Irenie Sztachelskiej powierzono Alicji Musiałowej) oraz uchwalono nowy statut.

Był to okres realizacji planu sześcioletniego (1950-1955). Budowane były fabryki (samochodów w Lublinie, Warszawie i inne), wielkie zakłady produkcyjne (Huta im. W. Lenina, Huta Warszawa, Zakłady Azotowe w Kędzierzynie i in.), rozwijały się miasta. Gospodarczy rozwój znalazł odzwierciedlenie w statutowych zapisach. Wśród wyszczególnionych zadań wymieniono patriotyczne wychowanie kobiet (członkiń Ligi i niezorganizowanych) w duchu dumy $z$ osiagnięć polskich mas pracujących $^{27}$. Dołączono też zapis dotyczący pogłębiania przyjaźni ze Związkiem Radzieckim i krajami demokracji ludowej. Wśród innych celów organizacji wymieniono: włączenie kobiet do pracy we wszystkich gałęziach gospodarki, mobilizowanie kobiet wiejskich do pracy nad podnoszeniem poziomu gospodarczego i kulturalnego wsi, zwiększenie troski o matkę i dziecko, budzenie odpowiedzialności kobiet za wychowanie „nowego pokolenia - budowniczych socjalizmu".

Zadania te LK miała realizować przez inspirowanie społecznej i kulturalno-wychowawczej aktywności szerokiego kręgu kobiet (robotnic, kobiet wiejskich, żon robotników, rzemieślników, gospodyń domowych, inteligentek). Jej celem było mobilizowanie kobiet do pracy w organizacjach (wymieniono Komitet Obrońców Pokoju i Towarzystwo Przyjaźni Polsko-Radzieckiej), radach narodowych i ich komisjach, świetlicach, spółdzielniach.

Nakreślone w statucie zadania służyły systemowi, który już ugruntował się w społeczeństwie. Statut ten obowiązywał przez 12 lat. W tym okresie Sejm uchwalił nową konstytucję (1952), w październiku 1956 r. wybuchł kryzys społeczno-polityczny, a po nim nastapiły wybory do Sejmu (1957), zmiany partyjne (w październiku 1956 r. I sekretarzem KC PZPR i faktycznym przywódca państwa został Władysław Gomułka), i odwilż, wzrastało zatrudnienie, przyspieszała industrializacja (budowa

26 Było to ważne wydarzenie, na tę okoliczność Poczta Polska wydała znaczek (cena 45 gr).

27 Statut stowarzyszenia „Liga Kobiet”, M.P. 1951, nr 61, poz. 821 [online] [dostęp: 10.11.2019]. Dostępny w World Wide Web: http://isap.sejm.gov.pl. 
mieszkań), ludzie uczestniczyli w odbudowie i rozbudowie gospodarki, rosło poczucie stabilizacji.

\section{Liga Kobiet (1963)}

W lutym 1962 r. odbył się III Krajowy Zjazd Ligi Kobiet. W przedzjazdowej i zjazdowej debacie Liga analizowała sytuację kobiet, która zmieniała się jednocześnie ze zmianami zachodzacymi w kraju. W popaździernikowej odwilży nastapiła liberalizacja życia politycznego (także złagodzenie cenzury), rząd odstapił od kolektywizacji rolnictwa, co znacznie neutralizowało dotychczasowa niechęć wsi do partyjnej władzy. Na poprawę sytuacji kobiet wpłynął gospodarczy rozwój kraju, w którym uczestniczyły. Kobiety były aktywne zawodowo i współpracowały z różnymi środowiskami i organizacjami.

Cele LK w przyjętym przez zjazd statucie były kontynuacją wcześniejszych założeń, sprzyjały rozwojowi aktywności i umacnianiu pozycji kobiet w społeczeństwie. „Podnoszenie poziomu świadomości, wiedzy, kwalifikacji zawodowych, kultury i umiejętności potrzebnych w życiu codziennym kobiet; zwiększenie udziału kobiet w socjalistycznym rozwoju kraju; umacnianie pozycji kobiety w gospodarce narodowej, w społeczeństwie i rodzinie", to główne cele Ligi Kobiet zawarte w statucie obowiąujacym od 10 kwietnia $1963 \mathrm{r}^{28}$

Zwracano uwagę na rozwój kobiet, ich kształcenie, zdobywanie awansów, chociaż nie było łatwe łączenie pracy zawodowej i domowej. Jak we wcześniejszych dokumentach, tak i teraz, doceniono rolę matki. Liga Kobiet miała organizować działalność „w kierunku wychowania młodego pokolenia na zdrowych, rzetelnych, należycie przygotowanych do życia i pracy ludzi, gorących patriotów Polski Ludowej”.

Liga i jej członkinie były władzy potrzebne do realizacji gospodarczych planów. W tym czasie realizowany był plan pięcioletni (1961-1965), wzrosło zatrudnienie, odbyły się wybory do Sejmu (1965) i rad narodowych (1965). W 1966 r. nastapiła reorganizacja LK, zlikwidowano koła w zakładach pracy, co znacznie wpłynęło na zmniejszenie liczebności

28 Statut Ligi Kobiet, M.P. 1963, nr 30, poz. 152 [online] [dostęp: 10.11.2019]. Dostępny w World Wide Web: http://isap.sejm.gov.pl. 
członkiń. Nie zmieniał się rząd i kierownicza rola partii, której przewodził Władysław Gomułka29.

\section{Liga Kobiet (1967)}

Zmiany w organizacji w 1967 r. zostały wymuszone rzadowymi decyzjami. Nie było już kół w większości zakładów pracy. Liga działała w nowych formach organizacyjnych i nowym środowisku. Skupiała się w miejscu zamieszkania. Szukała nowych form i metod, aby wzbudzić potrzeby zrzeszania się kobiet, aby zintegrować kobiece środowisko w blokach, osiedlach, miejscach zamieszkania.

Według statutu z 1967 r. Liga Kobiet wyznaczyła sobie trzy ogólne cele. „1. Podnoszenie poziomu ideowo-politycznego, wiedzy, kwalifikacji zawodowych, kultury i etyki oraz umiejętności potrzebnych w życiu codziennym kobiet; 2. Zwiększenie udziału kobiet w socjalistycznym rozwoju i we współrządzeniu krajem; 3. Umocnienie pozycji kobiety w gospodarce narodowej, w społeczeństwie i rodzinie" ${ }^{30}$. Zapis w dokumencie wskazywał na nowe postrzeganie kobiet w społeczeństwie i ich ról. Drugi raz wyeksponowano podnoszenie kwalifikacji (było w statucie w 1963 r.). Ten zapis odnosił się głównie do nowych środowisk (gospodynie domowe), w których teraz funkcjonowała Liga, a które do tej pory były mało aktywne. Pierwszy raz w statucie pojawił się zapis o „współrządzeniu krajem". Chodziło przede wszystkim o współdziałanie z radami narodowymi.

W okresie obowiazywania statutu w kraju miały miejsce poważne wydarzenia, które wpływały na zmiany społeczno-polityczne. To okres: niezadowolenia społecznego, wybuchających strajków ${ }^{31}$, rekonstrukcji w aparacie partyjnym, pięciu zjazdów PZPR i wyborów nowych władz partii $^{32}$, sześciu wyborów do Sejmu ${ }^{33}$, wybór Polaka Jana Pawła II na papieża (1978), powołanie Niezależnego Samorządnego Związku Zawodowego „Solidarność” (1980).

\footnotetext{
29 Pięciokrotnie premierem w latach 1947-1952 oraz 1954-1970 był Józef Cyrankiewicz.

30 Statut Ligi Kobiet, M.P. 1967, nr 26, poz. 279 [online] [dostęp: 10.11.2019]. Dostępny w World Wide Web: http://isap.sejm.gov.pl.

31 Ważne strajki w PRL przeprowadzono w latach: 1968, 1970, 1976, 1980, 1988.

32 Zjazdy PZPR: V - 1968, VI - 1971, VII - 1975, VIII - 1980, IX - 1981, X - 1986. Po Władysławie Gomułce (1956-1970) I sekretarzem KC PZPR był Edward Gierek (1970-1980), po nim Stanisław Kania (1980-1981) i Wojciech Jaruzelski (1981-1989).

33 Wybory parlamentarne odbyły się w latach: 1969, 1972, 1976, 1980, 1985, 1989.
} 


\section{Liga Kobiet Polskich (1981)}

Wydarzenia w kraju wpływały na funkcjonowanie organizacji. Atmosfera społecznego i politycznego niepokoju przenikała do kół i zarządów wszystkich szczebli. Członkinie Ligi Kobiet były parlamentarzystkami, we władzach partii, rad narodowych, sympatyzowały i wstępowały do NSZZ „Solidarność”.

W czerwcu 1980 r. na krajowej naradzie sekretarzy zarządów wojewódzkich LK dokonano oceny działalności organizacji, zdecydowano o zmianie programu, nazwy oraz o zwołaniu nadzwyczajnego zjazdu ${ }^{34}$. VIII Nadzwyczajny Zjazd Krajowy LK odbył się 28-29 listopada 1981 r. Zmieniła się przewodnicząca Zarządu Głównego, została nią Jadwiga Biedrzycka ${ }^{35}$. Delegatki Zjazdu podjęły „Uchwałę programowa”, w której podkreślono „wierność organizacji zasadom socjalizmu i poparcie dla Partii i jej poczynań chroniących zagrożone najcenniejsze dla kraju i narodu wartości"36.

Zjazd zdecydował o zmianie nazwy organizacji na Ligę Kobiet Polskich. Dwa tygodnie po Zjeździe, 13 grudnia 1981 r., w kraju został wprowadzony stan wojenny ${ }^{37}$. Według zapisu w dokumentach zmiana nazwy organizacji nastapiła 2 grudnia 1982 r. ${ }^{38}$

Zjazd uchwalił także zmiany w statucie organizacji. Do zadań LKP należało m.in.: umacnianie pozycji kobiet w życiu społeczno-politycznym i gospodarce narodowej; udział LKP w kształtowaniu polityki społecznej państwa; umacnianie ekonomicznej funkcji rodziny; podejmowanie działalności na rzecz pokoju i ładu społecznego w kraju; kształtowanie patriotycznych postaw i świadomości obywatelskiej, poczucia odpowiedzialności za losy kraju; udział LKP w rozwiązywaniu problemów związanych $z$ wprowadzeniem reformy gospodarczej ${ }^{39}$. Istotna dla organizacji regulacją był zapis w statucie o prawie zakładania kół Ligi w zakładach

\footnotetext{
34 Melania Mroczek-Szymańska, „Kalendarium Ligi Kobiet Polskich”, NP, nr 1, 1986, 33.

35 Jadwiga Biedrzycka była prezydentem Włocławka (1978-1981), wicemarszałkiem Sejmu (1985-1988), kierowała organizacją do $1989 \mathrm{r}$.

36 Melania Mroczek-Szymańska, „Kalendarium Ligi Kobiet Polskich”.

37 Stan wojenny został zniesiony 22.07.1983.

38 Rozporządzenie Rady Ministrów z dnia 2 grudnia 1982 r. w sprawie zmiany nazwy stowarzyszenia wyższej użyteczności "Liga Kobiet» na "Liga Kobiet Polskich" oraz nadania statutu temu stowarzyszeniu", Dz.U. 1982, nr 38, poz. 254 [online] [dostęp: 10.11.2019]. Dostępne w World Wide Web: http://isap.sejm.gov.pl.

39 Jolanta Szuszczykiewicz, „Co o Lidze Kobiet Polskich wiedzieć powinniśmy”, NP, nr 10, 1983, 5.
} 
pracy (był to powrót do sytuacji sprzed 1966 r.). Ta zmiana wpłynęła na zwiększenie liczebności członkiń LKP. W 1987 r. do Ligi należało 571776 kobiet skupionych w 11498 kołach $^{40}$.

Przyjęte przez Nadzwyczajny Zjazd zadania organizacji świadczyły o trosce o przyszłość kraju, przeżywającego ogromny kryzys, i o przyszłość kobiet. Nakreślone cele były także przejawem chęci uczestniczenia w rozwiąywaniu problemów. Rozgrywały się nowe, niepokojące wydarzenia: wzrastała opozycja wobec partii, wprowadzono podwyżkę cen, w maju i sierpniu 1988 r. wybuchly strajki.

\section{Liga Kobiet Polskich (1988)}

Liga Kobiet we wszystkich latach działalności zabiegała o skupienie w swoich szeregach jak największej liczby kobiet. Po konfliktach politycznych i stanie wojennym dużo członkiń i członków wypisywało się z PZPR. Topniały też szeregi Ligi, która od początku była ściśle związana $z$ komunistyczna partia. „Liga Kobiet Polskich jest społeczno-ideowa, masową organizacją kobiet polskich, działająca we wszystkich środowiskach, zrzeszająca kobiety niezależnie od ich światopoglądu i przynależności do innych organizacji społecznych lub politycznych", zapisano w postanowieniach ogólnych statutu z 1988 r. ${ }^{41}$ Była to jakby próba „przygarnięcia” kobiet, które odeszły $z$ partii, należały do związków zawodowych.

Cele organizacji w nowym statucie zostały zawarte $\mathrm{w}$ dziewięciu punktach. To m.in.: „Umacnianie pozycji kobiety w życiu publicznym, społecznym, zawodowym, kulturalnym i w gospodarce narodowej; dażenie do pełnej realizacji zasad równouprawnienia kobiet; reprezentowanie interesów kobiet w zakładach pracy; działanie na rzecz ochrony interesów kobiety, rodziny i dziecka"42. Cele Ligi wskazywały, że organizacja podjęła próbę „dopasowania” się do zmieniającej się rzeczywistości, ale jednak nadal trwała w politycznym uzależnieniu, o czym świadczyły zapisy w statucie, mówiące o „kształtowaniu moralności socjalistycznej” i upowszechnianiu kierunków socjalistycznego rozwoju społeczno-politycznego kraju.

40 „Stan organizacyjny Ligi Kobiet Polskich”, NP, nr 9, 1988, 25.

41 Zarzadzenie Ministra Spraw Wewnętrznych z dnia 30 listopada 1988 r. w sprawie ustalenia i ogłoszenia statutu stowarzyszenia wyższej użyteczności „Liga Kobiet Polskich”, M.P. 1988, nr 33, poz. 301 [online] [dostęp: 10.11.2019]. Dostępne w World Wide Web: http:/ / isap.sejm.gov.pl.

42 Ibidem. 
Nakreślone cele były wyraźnie oderwane od ówczesnych realiów. Kobiety raczej nie myślały o umacnianiu swojej pozycji publicznej, gdy w kraju panowało napięcie polityczne, gospodarka pograżała się w kryzysie, a społeczeństwo ogarniała atmosfera niepewności. Upadał socjalistyczny ustrój. Od lutego do kwietnia 1989 r. trwały obrady Okragłego Stołu, w czerwcu 1989 r. odbyły się wybory parlamentarne (zakończone klęską obozu władzy), a w listopadzie 1990 r. wybory prezydenckie, w których zwyciężył przewodniczący „Solidarności” Lech Wałęsa.

Zmiana ustroju stała się faktem. I wywołała w Lidze kryzys. W czasie politycznych wydarzeń członkinie opuszczały organizację. $\mathrm{Na}$ początku 1989 r. do Ligi należało jeszcze 585550 kobiet skupionych w 11905 kołach $^{43}$. Na początku lat 90. organizacja skupiała ok. 6 tys. kobiet w 20 oddziałach terenowych ${ }^{44}$.

\section{Zakończenie}

Analiza celów Ligi Kobiet, zawartych w kolejnych edycjach statutów, prowadzi do wniosku, że ich realizację (działalność Ligi) należy postrzegać w dwojaki sposób. $Z$ jednej strony organizacja była wykorzystywana do popierania ówczesnego ustroju, partyjnego systemu zarządzania i kształtowania politycznej świadomości kobiet, co jednoznacznie wynika ze statutowych zapisów („wierność organizacji zasadom socjalizmu”, „udział kobiet w socjalistycznym rozwoju kraju”, „kształtowanie moralności socjalistycznej”). $Z$ drugiej zaś strony Liga skupiała się na umacnianiu pozycji kobiet w społeczeństwie, rozwijaniu ich aktywności zawodowej i społecznej, zabieganiu o poprawę ich warunków życia. Te cele ewoluowały w kolejnych latach pod wpływem politycznych i społecznych przeobrażeń zachodzących w kraju. Świadczyły o tym statutowe zapisy: „podnoszenie kwalifikacji”, udział we „współrządzeniu krajem”, budowanie „pozycji kobiety w gospodarce narodowej”.

$Z$ analizy zadań Ligi wyłania się konkluzja, że organizacja była blisko codziennych trosk i problemów kobiet. W rzeczywistości „polityczne cele" zapisane w statutach często były - można stwierdzić - obok codziennych zadań i problemów zwiazanych z praca, rodzina, edukacja i innych, które wówczas się pojawiały. Warto chociażby wspomnieć, że

43 „Liga Kobiet Polskich w liczbach”, NP, nr 5, 1989,15.

44 Małgorzata Dajnowicz, „Posłanki Ligi Kobiet Polskich”, 215. 
dzięki staraniom Ligi kobiety miały wsparcie i pomoc w skomplikowanych sytuacjach rodzinno-prawnych, powołano fundusz alimentacyjny, instytucje opiekunów społecznych, sady rodzinne, komitety opieki społecznej, zakładano żłobki, przedszkola ${ }^{45}$.

Liga Kobiet, tak jak to określiła jej pierwsza przewodniczaca Irena Sztachelska, przez lata służyła państwu i kobietom. Była obecna w „ogólnym biegu prac i walki”46.

\section{Bibliografia}

\section{Źródla archiwalne i biblioteczne}

Deklaracja ideowa Społeczno-Obywatelskiej Ligi Kobiet, Archiwum Akt Nowych (dalej: AAN), zespół Społeczno-Obywatelska Liga Kobiet Zarząd Główny w Warszawie, nr 888, sygn. 1.

„Liga Kobiet Polskich w liczbach”, Nasza Praca (dalej: NP), nr 5, 1989.

Mroczek-Szymańska, Melania. „Kalendarium Ligi Kobiet Polskich”, NP, nr 1, 1986.

„Od redakcji”, NP, nr 1, 1986.

„Stan organizacyjny Ligi Kobiet Polskich”, NP, nr 9, 1988.

Statut Społeczno-Obywatelskiej Ligi Kobiet, AAN, zespół Ministerstwa Pracy

i Opieki Społecznej (dalej: MPiOS) (1945-1946), nr 402, sygn. 300.

Statut Społeczno-Obywatelskiej Ligi Kobiet, AAN, zespół MPiOS (19471948), nr 402, sygn. 323.

Statut Towarzystwa Ligi Kobiet Polskich (1917), AAN, zespół Liga Kobiet Polskich, 57/II, sygn. 37.

Statut Towarzystwa Ligi Kobiet Polskich (1919), AAN, zespół Liga Kobiet Polskich, 57/II, sygn. 150.

Statut Towarzystwa „Liga Kobiet” zatwierdzony przez Komisariat Rządu na m.st. Warszawę w dn. 2 marca 1928 r., AAN, zespół Liga Kobiet Polskich, $57 /$ II, sygn. 150.

Szuszczykiewicz, Jolanta. „Co o Lidze Kobiet Polskich wiedzieć powinniśmy”, NP, nr 10, 1983.

45 Jolanta Szuszczykiewicz, „Co o Lidze Kobiet Polskich wiedzieć powinniśmy”, NP, nr 10, 1985, 3.

46 „Od redakcji”, NP, nr 1, 1986, 1. 
Szuszczykiewicz, Jolanta. „Co o Lidze Kobiet Polskich wiedzieć powinniśmy”, NP, nr 10, 1985.

\section{Źródła internetowe}

Obwieszczenie Prezesa Rady Ministrów z dnia 5 października 1949 r. w sprawie ogłoszenia statutu stowarzyszenia wyższej użyteczności „Liga Kobiet”, M.P. 1949, nr 73, poz. 923 [online] [dostęp: 10.11.2019]. Dostępne w World Wide Web: http://prawo.sejm.gov.pl.

Rozporządzenie Rady Ministrów z dnia 9.09.1949 r. w sprawie uznania stowarzyszenia „Liga Kobiet” za stowarzyszenie wyższej użyteczności, Dz.U. 1949, nr 5 [online] [dostęp: 10.11.2019]. Dostępne w World Wide Web: http:/ / isap.sejm.gov.pl.

Rozporządzenie Rady Ministrów z dnia 2.12.1982 r. w sprawie zmiany nazwy stowarzyszenia wyższej użyteczności „Liga Kobiet” na „Liga Kobiet Polskich” oraz nadania statutu temu stowarzyszeniu, Dz.U. 1982, nr 38 [online] [dostęp: 10.11.2019]. Dostępne w World Wide Web: http://isap.sejm.gov.pl.

Statut Ligi Kobiet, M.P. 1963, nr 30, poz. 152 [online] [dostęp: 10.11.2019]. Dostępny w World Wide Web: http://isap.sejm.gov.pl.

Statut Ligi Kobiet, M.P. 1967, nr 26, poz. 279 [online] [dostęp: 10.11.2019]. Dostępny w World Wide Web: http://isap.sejm.gov.pl.

Statut stowarzyszenia „Liga Kobiet”, M.P. 1951, nr 61, poz. 821 [online] [dostęp: 10.11.2019]. Dostępny w World Wide Web: http://isap.sejm.gov.pl.

Zarzadzenie Ministra Spraw Wewnętrznych z dnia 30 listopada 1988 r. w sprawie ustalenia i ogłoszenia statutu stowarzyszenia wyższej użyteczności „Liga Kobiet Polskich”, M.P. 1988, nr 33, poz. 301 [online] [dostęp: 10.11.2019]. Dostępne w World Wide Web: http://isap.sejm.gov.pl.

\section{Opracowania}

Ćwik, Urszula. „Podstawowe założenia Społeczno-Obywatelskiej Ligi Kobiet w świetle "Mody i Życia Praktycznego" (1946-1951)", w: Małgorzata Dajnowicz, Adam Miodowski (red.), Polityka i politycy w prasie XX i XXI wieku. Prasa organizacji politycznych, (Białystok: Wydawnictwo Humanica, 2017), 49-58. ISBN 978-83-946177-3-8.

Dajnowicz, Małgorzata. „Działalność Społeczno-Obywatelskiej Ligi Kobiet w świetle "Naszej Pracy» (1947-1949)”, w: Małgorzata Dajnowicz, Adam 
Miodowski (red.), Polityka i politycy $w$ prasie XIX i XX wieku, (Białystok: Wydawnictwo Humanica, 2016), 295-307. ISBN 978-83-946177-0-7.

Dajnowicz, Małgorzata. „Główne kierunki działalności Ligi Kobiet w Polsce Ludowej do 1975 roku (ze szczególnym uwzględnieniem województwa białostockiego)", Zeszyty Naukowe Uniwersytetu Jagiellońskiego. Prace Historyczne, t. 145, z. 3, 2018, 579-601. ISSN 0083-4351.

Dajnowicz, Małgorzata. „Posłanki Ligi Kobiet Polskich i wybory parlamentarne 1989 roku (prezentacja w świetle "Zwierciadła»)", w: Małgorzata Dajnowicz, Adam Miodowski (red.), Polityka i politycy w prasie XX i XXI wieku. Polityka w prasie kobiecej, (Białystok: Wydawnictwo Uniwersytetu w Białymstoku, 2019), 205-215. ISBN 978-83-7431-561-6.

Dajnowicz, Małgorzata. "Zwierciadło" - platforma polityczna Ligi Kobiet w okresie PRL (1957-1961, 1982-1989)", Rocznik Historii Prasy Polskiej, t. 20, z. 3(47), 2017, 67-90. ISSN 1509-1074.

Drozdowska, Agnieszka. „Działalność Ligi Kobiet w północno-wschodniej części Polski Ludowej w latach 1975-1989 w świetle "Naszej Pracy»", Niepodległość i Pamięć, nr 2, 2019, 184-210. ISSN 1427-1443.

Drozdowska, Agnieszka. „O działalności Ligi Kobiet w okręgu białostockim (w świetle "Naszej Pracy»)", w: Małgorzata Dajnowicz, Adam Miodowski (red.), Polityka i politycy $w$ prasie XX i XXI wieku. Polityka $w$ prasie kobiecej, (Białystok: Wydawnictwo Uniwersytetu w Białymstoku, 2019), 185-204. ISBN 978-83-7431-561-6.

Miodowski, Adam. „Rozwój dolnośląskich i zachodniopomorskich struktur Społeczno-Obywatelskiej Ligi Kobiet w latach 1947-1949 w świetle publikacji "Naszej Pracy»", w: Małgorzata Dajnowicz, Adam Miodowski (red.), Polityka i politycy $w$ prasie XX $i$ XXI wieku. Polityka $w$ prasie kobiecej, (Białystok: Wydawnictwo Uniwersytetu w Białymstoku, 2019), 167-183. ISBN 978-83-7431-561-6.

\section{Publikacje internetowe}

Dufrat, Joanna. „Powstanie Ligi Kobiet i działalność w okresie I wojny światowej" [online] [dostęp: 1.07.2020]. Dostępne w World Wide Web: http:/ /ligakobietpolskich.pl/wp-content/uploads/2013/12/Powstanie-Ligi-Kobiet-i-dzia\%C5\%82alno\%C5\%9B\%C4\%87-w-okresie-I-wojny-\%C5\%9Bwiatowej_dr_Dufrat.pdf. 